\title{
The impact of soil erosion on soil fertility and vine vigor. A multidisciplinary approach based on field, laboratory and remote sensing approaches
}

\author{
Agata Novara ${ }^{\mathrm{a}, *}$, Antonino Pisciotta $^{\mathrm{a}}$, Mario Minacapilli ${ }^{\mathrm{a}}$, Antonino Maltese ${ }^{\mathrm{b}}$, Fulvio Capodici ${ }^{\mathrm{b}}$, \\ Artemi Cerdà ${ }^{\mathrm{c}}$, Luciano Gristina ${ }^{\mathrm{a}}$ \\ a Dept. of Agricultural, Food and Forest Sciences University of Palermo, Palermo, Italy \\ ${ }^{\mathrm{b}}$ Dept. of Civil, Environmental, Aerospace, Materials Engineering, University of Palermo, Italy \\ c Soil Erosion and Degradation Research Group, Department of Geography, University of Valencia, Valencia, Blasco Ibàñez 28, 46010, Valencia, Spain
}

\section{H I G H L I G H T S}

- Soil erosion in vineyards has a strong effect on soil organic carbon loss and redistribution.

- The interactions among vines vigor, sediment delivery and SOC was analyzed.

- Soil fertility land unit was reduced by $40 \%$ and SOC decreased by $0.20 \mathrm{Mg} \mathrm{ha}^{-1} \mathrm{y}^{-1}$

- Vine vigor was strongly correlated to WEOC components.

- Soil-plant analyses can detect vineyard fertility, monitoring risk areas in the long term.

\section{A R T I C L E I N F O}

\section{Article history:}

Received 5 July 2017

Received in revised form 23 November 2017

Accepted 24 November 2017

Available online 13 December 2017

\section{Keywords:}

Carbon stock

Viticulture

Erosion

Specific ultraviolet absorbance

NDVI
G R A P H I C A L A B S T R A C T

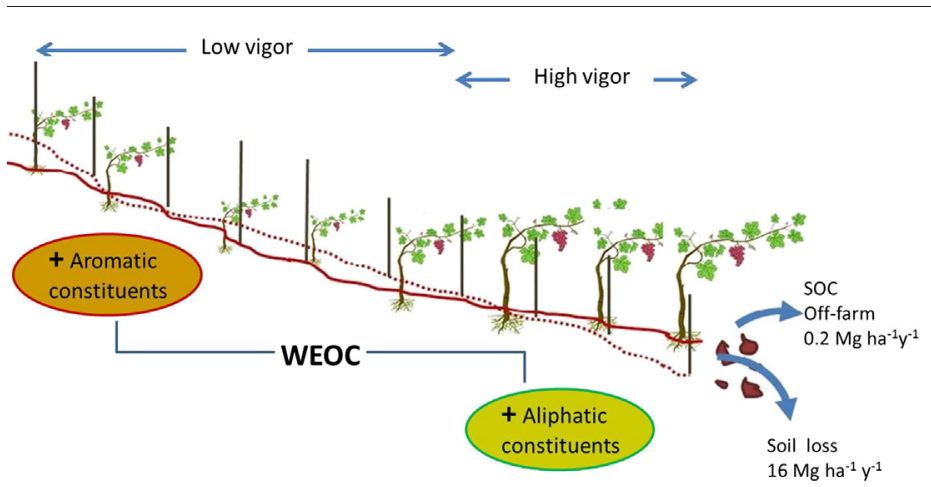

\section{A B S T R A C T}

Soil erosion processes in vineyards, beyond surface runoff and sediment transport, have a strong effect on soil organic carbon (SOC) loss and redistribution along the slope. Variation in SOC across the landscape can determine differences in soil fertility and vine vigor. The goal of this research was to analyze the interactions among vines vigor, sediment delivery and SOC in a sloping vineyard located in Sicily. Six pedons were studied along the slope by digging 6 pits up to $60 \mathrm{~cm}$ depth. Soil was sampled every $10 \mathrm{~cm}$ and SOC, water extractable organic carbon (WEOC) and specific ultraviolet absorbance (SUVA) were analyzed. Erosion rates, detachment and deposition areas were measured by the pole height method which allowed mapping of the soil redistribution. The vigor of vegetation, expressed as Normalized Difference Vegetation Index (NDVI), derived from highresolution satellite multispectral data, was compared with measured pruning weight. Results confirmed that soil erosion, sediment redistribution and SOC across the slope was strongly affected by topographic features, slope and curvature. The erosion rate was $16 \mathrm{Mg} \mathrm{ha}^{-1} \mathrm{y}^{-1}$ since the time of planting (6 years). SOC redistribution was strongly correlated with the detachment or deposition areas as highlighted by pole height measurements. The off-farm SOC loss over six years amounted to $1.2 \mathrm{Mg} \mathrm{C} \mathrm{ha}^{-1}$. SUVA 254 values, which indicate hydrophobic material rich in aromatic constituents of WEOC, decreased significantly along the slope, demonstrating that WEOC in the detachment site is more stable in comparison to deposition sites. The plant vigor was strongly correlated with WEOC constituents. Results demonstrated that high resolution passive remote sensing data

\footnotetext{
* Corresponding author.

E-mail address: agata.novara@unipa.it (A. Novara).
} 
combined with soil and plant analyses can survey areas with contrasting SOC, soil fertility, soil erosion and plant vigor. This will allow monitoring of soil erosion and degradation risk areas and support decision-makers in developing measures for friendly environmental management.

\section{Introduction}

Soils are important natural resources for food production. However, they are affected by several soil degradation factors with consequent significant impacts on agricultural productivity and environmental and human health (Brevik et al., 2015; Brevik et al., 2017; Blum, 2013; Steffan et al., 2017). Erosion is considered one of the most widespread human induced causes of land degradation, impacting crop yields and threatening the soil system and sustainability of human societies (Mol and Keesstra, 2012). This is why the importance of soils has been highlighted to achieve the United Nations Goals for Sustainability (Keesstra et al., 2016). Erosion leads to loss of nutrients, lower soil water holding capacity, decrease thickness of the soil layer that is most useful for plant growth, and reduction in soil fertility and biodiversity (García-Díaz et al., 2017; Li et al., 2016). The effect of erosion on loss of productivity for arable land has been widely studied, quantifying the value in economic terms (Williams et al., 1984), which also make it necessary to develop an economic and biophysical approach to management that contributes to soil restoration (Cerdà et al., 2017). den Biggelaar et al. (2003), in a literature review on the effects of erosion on soil productivity, estimate that relative wheat yield losses ranged from $0.04 \% \mathrm{yr}^{-1}$ in Europe to $0.67 \% \mathrm{yr}^{-1}$ in Australia. Such loss of productivity undermines food production with several negative economic effects. Loss of productivity due to land degradation has a direct impact on net income, but while the farmers' perception of this reduction and the economic evaluation can be easy in some crops (i.e. cereal yield), it is more difficult for other productions such as grapes. The market for grapes for wine and table production, in fact, is mainly focused on grape quality rather than quantity. Therefore, the effects of erosion in vineyards should be evaluated not only on grape yield, but also on plant fertility and vigor, which are the key indicators of final wine quality (Wezel et al., 2002; Zingore et al., 2007). Erosion is responsible for soil nutrient losses and negative effects on plant nutrition. To restore soils affected by erosion and recover their fertility there is a need to increase external chemical inputs to maintain plant vigor (Zingore et al., 2007). The use of fertilizes and passes by heavy machinery leads to noteworthy reductions in vineyard sustainability due to increases in costs at the farm level, water pollution, soil erosion rates, and higher $\mathrm{CO}_{2}$ emissions (Cerdà et al., 2017). Under stable conditions, soil erosion by water is a natural process generally in balance with natural soil formation due to weathering, but human activities considerably increase the magnitude of soil erosion over equilibrium levels with several impacts on the environment (Zhang et al., 2017). Most Mediterranean hilly vineyards exceed such equilibrium with erosion rates ranging from few tons of sediment to $100 \mathrm{Mg} \mathrm{ha}^{-1} \mathrm{y}^{-1}$ (Novara et al., 2011; Rodrigo-Comino et al., 2016a, 2017; Ruiz-Colmenero et al., 2013). Similar high erosion rates have also been found in vineyards under temperate climate conditions (Rodrigo-Comino et al., 2016b). Moreover, the impact of vineyard cultivation on erosion risk is exacerbated by improper management such as soil tillage, low organic matter contents, biomass removal and limited percentage of soil cover (Prosdocimi et al., 2016). The effect of soil erosion on sediment loss has been widely elucidated, but the influence of erosion processes on soil organic carbon (SOC) cycling is still poorly understood and contradictory findings have been reported (Doetterl et al., 2016). Soil erosion could have a negative impact on $\mathrm{C}$ sequestration, being a source for atmospheric $\mathrm{CO}_{2}$ (Novara et al., 2016) due to a decrease in net primary production on eroded soil and a higher SOC decomposition in buried sediments (Jacinthe and Lal, 2001; Lal and Pimentel, 2008). On the other hand, some studies have found that erosion of agricultural soils is a sink for atmospheric $\mathrm{CO}_{2}$. The eroded sediments buried at deposition sites are protected from quick decomposition, therefore the organic matter turnover rates are reduced (Van Oost et al., 2008). Although soil erosion could be considered a positive process for $\mathrm{CO}_{2}$ reduction, in agricultural land it has a negative impact on ecosystem services, considering that fertile soils are degraded and the effects of dissolved organic carbon dynamics in the aquatic environment (Whitehead et al., 2006). The reduction of agricultural land fertility and crop productivity as a consequence of soil erosion is widely recognized by researchers but the difficulties in quantification of SOC loss and the specific delineation of C deposition/ erosion sites has resulted in a weak perception of the risk by farmers and stakeholders (Moges and Holden, 2008). Estimations of SOC loss in a sloping area have been determined through SOC cycle and erosion models, providing useful information on $\mathrm{C}$ balance and total SOC loss off farm, but further knowledge on the redistribution of bulk SOC and SOC pools along the slope are needed for specific agricultural production purposes. Therefore, in agricultural soils, knowledge of $\mathrm{C}$ loss should be integrated with evaluation of SOC dynamics to define the stability of the SOC pool in conjunction with measurement of plant vigor to estimate the loss of fertile area. Considering the hypothesis of a strong relationship existing between sediment erosion, carbon losses and plant vigor, the goal of this study was to analyze, in a Mediterranean vineyard: (i) soil erosion rates and SOC losses, and their interaction; (ii) impact of soil erosion and C distribution on plant vigor; and (iii) interaction between indirect (NDVI) and direct (pruning weight) methods of plant vigor estimation with soil erosion rates and SOC distribution.

\section{Materials and methods}

\subsection{Study area and soil analysis}

A vineyard (cultivar Viognier) located in Menfi, in southwestern Sicily $\left(37^{\circ} 34^{\prime} \mathrm{N}, 12^{\circ} 59^{\prime} \mathrm{E}\right)$, was selected as representative of Mediterranean vineyards: steep slopes, shallow soils, and millennia of ploughing. The area is characterized by a Mediterranean climate (summer drought), with mean annual temperature of $18{ }^{\circ} \mathrm{C}$ and mean annual precipitation of $516 \mathrm{~mm}$. The soils are Calcic-gleyic-vertisols according to WRB (2006) ( clay $=42.0 \%$, silt $=37.2$, sand $=20.8 \% ; \mathrm{pH}=8 ; \mathrm{CaCO}_{3}=$ $22 \%$ ) (unpublished data, Assessorato Regionale Agricoltura, dello Sviluppo Rurale e della Pesca Mediterranea-Ufficio Intercomunale di Menfi). The vineyard has an area of 3 ha and lies on an E-NE facing hillside with an average slope of $9.5 \%$. The vineyard is located on a hydraulically disconnected slope, according to field observations. It was planted in 2011 with a $2.40 \mathrm{~m}$ distance between rows and $1 \mathrm{~m}$ distance intra-row. The vines were cane pruned and a vertical shoot positioning trellis system was used at fruit set. The vineyard was traditionally managed with four or five shallow tillage passes ( $10 \mathrm{~cm}$ depth) during the year to control weeds, water evaporation and avoid the formation of soil cracks. Conventional cultivation practices for the production of healthy grapes were used. Along the slope, in the vineyard intra-row, six pedons were studied by digging six pits (W1 to W6) up to $60 \mathrm{~cm}$ depth (Fig. 1) during the summer of 2016. Pit positions along the slope were chosen after vineyard pole height measurements which was helpful to discriminate deposition and detachment areas. In each pit, 3 soil samples were collected every $10 \mathrm{~cm}$ depth up to $60 \mathrm{~cm}$ depth (total soil samples 84 ), sieved at $2 \mathrm{~mm}$ and stored for soil organic carbon (SOC) analysis. An EA-IRMS (Elemental Analyser Isotope Ratio 

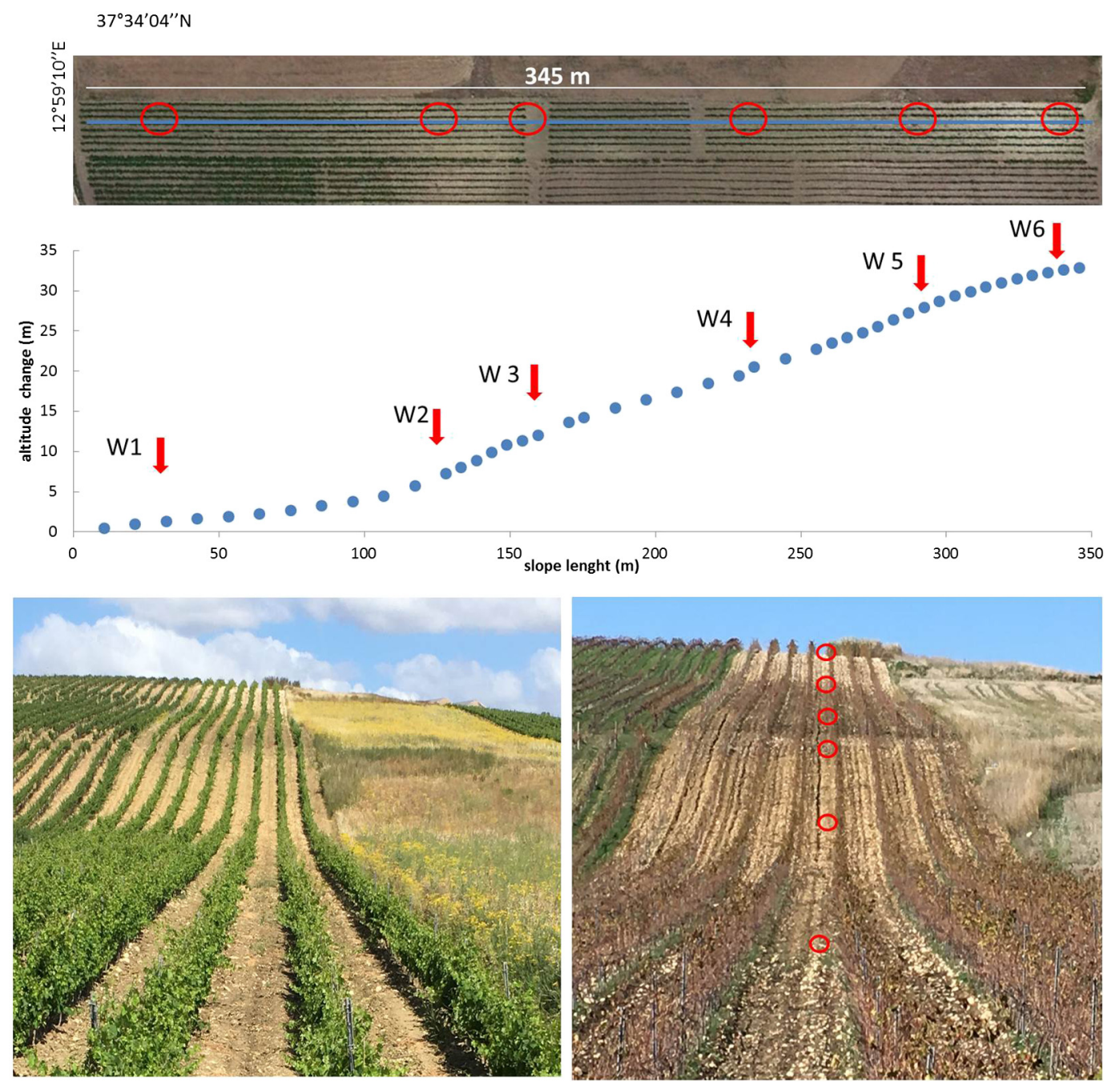

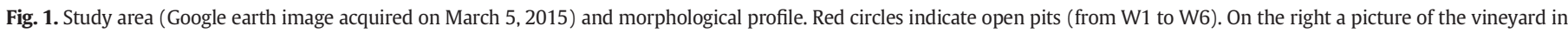
winter, on the left a picture of the vineyard in spring.

Mass Spectrometry, Carlo Erba Na 1500, model Isoprime 2006, Manchester, UK) was used for SOC determination after removing carbonates through soil acidification.

Water extractable organic carbon (WEOC) was obtained by shaking aliquots of soil with $0.5 \mathrm{M} \mathrm{K}_{2} \mathrm{SO}_{4}$ for $1 \mathrm{~h}$ followed by centrifugation and filtration of the supernatant through a cellulose acetate membrane filter $(<0.45 \mu \mathrm{m})$. Organic $C$ contents of the soil extracts were determined by Pt-catalyzed, high temperature combustion $\left(680^{\circ} \mathrm{C}\right)$ after acidification $(\mathrm{pH}=2)$ followed by infrared detection of $\mathrm{CO}_{2}$ (Vario TOC, Elementar, Hanau, Germany). In order to study the quality of WEOC compounds, UV absorbance of the soil extracts at 254 and $285 \mathrm{~nm}$ were determined by means of an Agilent 8453 spectrophotometer. Specific UV absorbance values $\left(\mathrm{SUVA}_{254}\right.$ and $\mathrm{SUVA}_{285}$ ) were calculated by normalizing absorbance values to the concentration of organic $C$ in the extracts (Weishaar et al., 2003).

\subsection{Soil erosion assessment}

The slope of the soil surface was measured at $5.30 \mathrm{~m}$ intervals along the vineyard's slope through field reliefs. The erosion rate was estimated using the pole method (Novara et al., 2011). During plantation of vines, poles were carefully planted to a standard depth using a machine. When erosion was determined, the difference $(h)$ between the pole over ground height in three rows and the pole height during installation
$(160 \mathrm{~cm})$ was measured. The area index $(I)$ was calculated as follows:

$I=\frac{\mathrm{h}_{\mathrm{f}, 1}-\mathrm{h}_{\mathrm{f}, 1+n}}{h_{i}}$

where $h_{f, 1}$ is the over-ground height of a pole at the present time, $h_{f, 1+n}$ is the height of the next pole at a lower elevation, and $h_{\mathrm{i}}$ is the pole height at installation. Positive values for the $I$ index represent soil erosion, while negative values represent soil deposition.

\subsection{Soil organic carbon loss}

The SOC loss off farm was estimated as follows:

SOCloss $=\sum_{\mathrm{i}=1}^{n} \frac{\left(\mathrm{SOCS}_{\mathrm{i}}+\mathrm{SOC}_{\mathrm{ref}}\right)^{*}}{2} \mathrm{E}_{\mathrm{i}}-\sum_{\mathrm{j}=1}^{n} \operatorname{SOCs}_{\mathrm{j}}{ }^{*} \mathrm{E}_{\mathrm{j}}$

where the SOCref is SOC reference corresponding to the SOC content ( 0 $10 \mathrm{~cm}$ depth) in the flat area on the top of the slope, $n$ is the number of intervals in which the slope was divided (each interval was $5.30 \mathrm{~m}$ long in the case study corresponding to the pole distance along the row); SOCs $\mathrm{s}_{\mathrm{i}}$ is the SOC content in the first $10 \mathrm{~cm}$ soil depth in each detachment area interval; $E_{i}$ is the soil detachment $\left(\mathrm{Mg} \mathrm{ha}^{-1}\right)$ in each interval, the SOC $_{\mathrm{j}}$ is the SOC in the first $10 \mathrm{~cm}$ in each deposition area interval and 
Ej is the soil deposited in each interval. The values of SOCs $s_{i}$ and $\operatorname{SOCs}_{j}$ were acquired after the spatial distribution of SOC determined with a contour graph.

\subsection{Vegetation analysis}

The effect of soil erosion and SOC distribution on plant vigor was analyzed using the Normalized Difference Vegetation Index (NDVI) (Rouse et al., 1973) and measurements of pruning residues. NDVI, based on a simple combination of reflectance values in red and nearinfrared regions, is widely used to infer crop variables like biomass, LAI, plant coverage and chlorophyll (Christensen and Goudriaan, 1993; Aparicio et al., 2000).

NDVI is generally computed using the following expression:

$\mathrm{NDVI}=\frac{\mathrm{NIR}-\mathrm{RED}}{\mathrm{NIR}+\mathrm{RED}}$

A high resolution RapidEye image (5 $\mathrm{m}$ of pixel spacing) was acquired on the 15th of July 2013. It was reflectance calibrated and atmospherically corrected by means of the 6S (Second Simulation of a Satellite Signal in the Solar Spectrum) radiative transfer code (Vermote et al., 1997). Reflectance values of red (RED 630-685 nm) and near infrared (NIR, 760-850 nm) bands were used to derive the NDVI spatial distribution over the area. Pruning mass was collected and analyzed during the 2016 vegetative season for in situ analysis. In winter, the vines were pruned to maintain the same number of buds ( 8 buds per cane and 2 buds per spur). Twenty plants, on the two rows adjacent to the pit (ten vines for each row), were sampled to measure the pruning mass. Pruned shoots from each vine were dried and weighed to calculate the biomass per vine. The pruning mass was preferred as a plant vigor indicator rather than grape yield because it is less dependent on climatic conditions.

\subsection{Statistical analysis}

Correlation analysis among SOC, WEOC quality (SUVA) and plant vigor was carried out on data collected next to the pits SAS statistical programs were used (SAS Institute, 2001). Contour graphs for SOC and $S_{U V A}$ values were carried out using inverse distance to a Power (SURFER software version 7.00). In order to analyze the spatial variability of SOC and SUVA, two contour graphs were generated by means of the inverse-distance weighting (IDW) method (Burrough and McDonnell, 1998) using the SURFER software package assuming a distance-decay value equal to 2 and a number of points within the neighborhood equal to 8 as IDW parameters.

\section{Results and discussion}

\subsection{Soil erosion assessment}

The pole method allowed the variation of soil profile morphology, deposition and detachment areas to be monitored in order to study SOC distribution following erosion processes. The variation in pole height between July 2016 and the pole installation (2011) showed the topographical changes that had taken place over the intervening years (Fig. 2). The $h$ value ranged from $-11 \mathrm{~cm}$ to $+12 \mathrm{~cm}$, as shown in Fig. 2. The I index values (calculated according Eq. 3 ) highlighted the areas of sedimentation or erosion along the slope. The difference in height between two consecutive poles provided useful information on concavity or convexity of the soil surface and therefore on the ability to accumulate nutrients and SOC. The values were negative next to W1 and W5 (W1 $=-0.016$; W5 $=-0.009$ ) while they were positive close to the other pits, ranging from 0.003 to 0.012 at pits W6 and W2, respectively. Negative values indicated areas of deposition, while positive values indicated areas of detachment. The total erosion volume was calculated as the difference between the detachment and deposition zones. The annual erosion rate was $16 \mathrm{Mg} \mathrm{ha}^{-1} \mathrm{y}^{-1}$. Other studies have found similar erosion rates in Mediterranean vineyards (Kirchhoff et al., 2017; Prosdocimi et al., 2016; Rodrigo-Comino et al., 2016a). Vineyards show the highest erosion rates of the various Mediterranean crops due to the deep geomorphological impact of the land leveling performed by heavy machinery works to plant new vineyards (Cerdà et al., 2017; Ramos and Martínez-Casasnovas, 2007). The new plantations, in fact, contribute more to soil losses than older established vineyards due to human trampling and machinery movement during the planting period (Rodrigo-Comino et al., 2016c). The high erosion rates measured in vineyards are also determined by slope angle and surface roughness (Battany and Grismer, 2000), frequent tillage practices (Lieskovský and Kenderessy, 2014) and limited use of cover cropping (Blavet et al., 2009). Paroissien et al. (2010) used a topographical method, very similar to the pole technique used here, to confirm long-term high erosion rates in French vineyards, which was also previously found by Casalí et al. (2009) in Navarre using botanical benchmarks. There is agreement within the scientific community that vineyards are not sustainable under current prevailing management practices and therefore the use of alternative practices to control erosion (mulching,

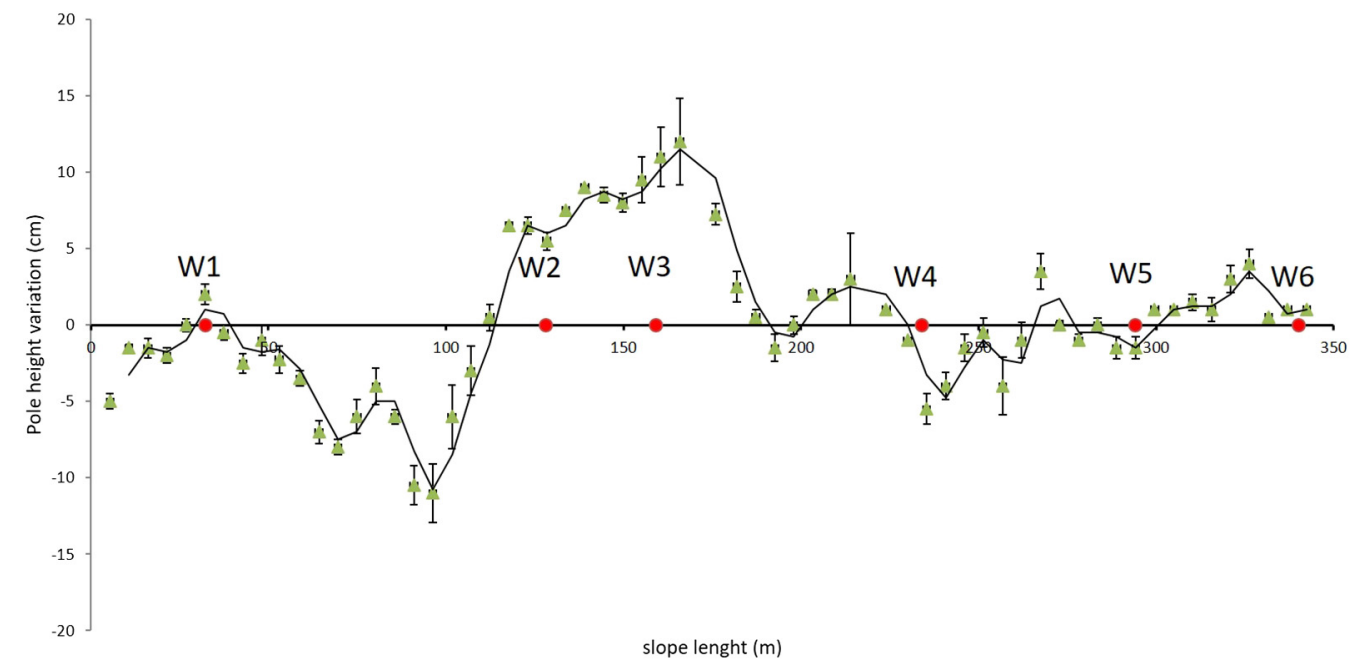

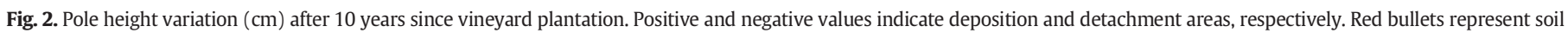
sampling points. 
a
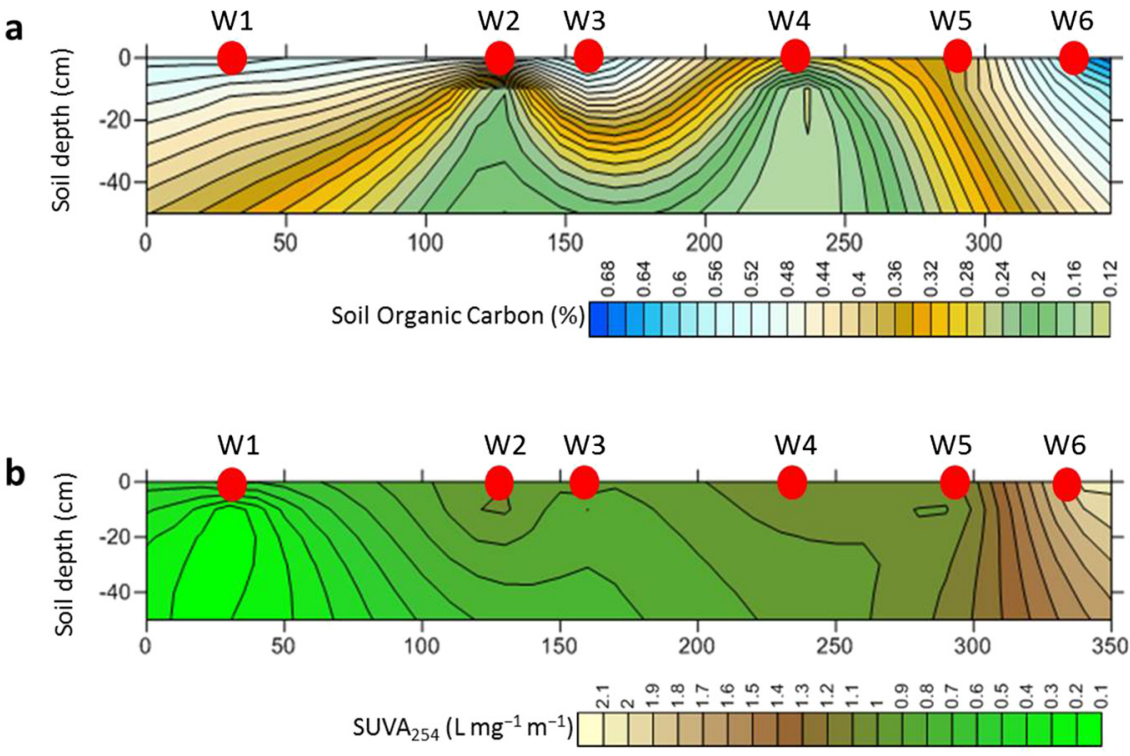

C

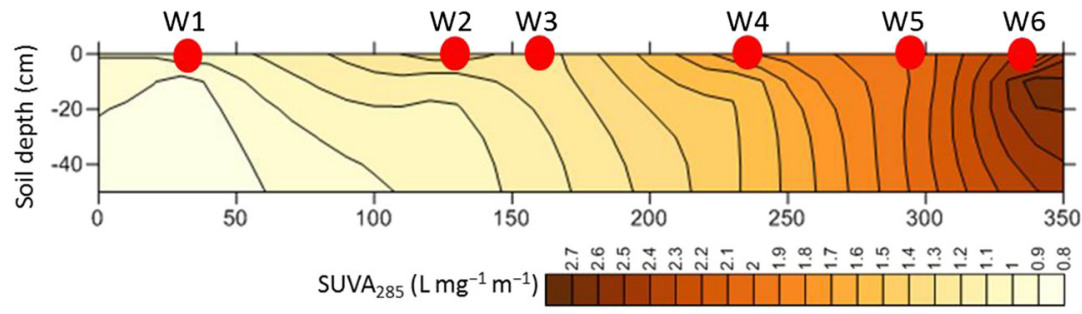

d

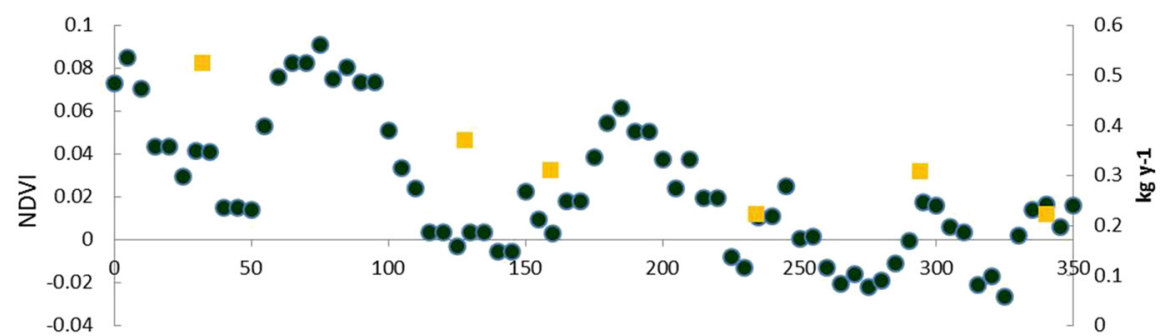

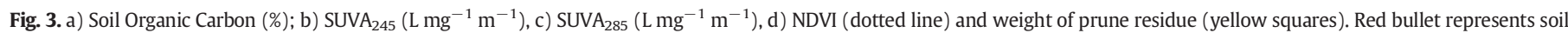
sampling points.

rock fragment and cover cropping) should be investigated and utilized (Prosdocimi et al., 2016; Ruiz-Colmenero et al., 2011).

\subsection{Soil organic carbon distribution and loss}

Soil organic carbon content in the surface soil layer $(0-10 \mathrm{~cm})$ was significantly correlated to the detaching or depositional areas (pole heights) ( $n=6 ; p \leq 0.04)$, ranging from $3.4 \mathrm{~g} \mathrm{Kg}^{-1}$ in pit W5 (deposition area) to $7.4 \mathrm{~g} \mathrm{Kg}^{-1}$ in pit W2 (detachment area). The spatial distribution of SOC data showed its highest values at the bottom and top parts of the slope. The high SOC content founded in the deposition area (bottom of the slope) is explained by the deposition of fine soil particles that are rich in OC; while the high value of SOC at the top of the slope is due to a low detachment rate, given that this part of the slope is hydrologically isolated and does not receive runoff from above.

The measured erosive phenomenon is a consequence of the intense ploughing, bare soils, and row direction (oriented up and down the slope) that favours runoff reaching the bottom of the slope without any sink area. Considering the whole observed soil depth, the highest SOC content was measured in the deposition area at the bottom of the slope due to the deposition of fine soil particles rich in organic matter that were easily transported from the upper and middle parts of the slope. The high organic C content of the soils at the upper slope part (shoulder) is due to the low slope angle that reduces soil losses as this part of the slope is hydrologically disconnected. Splash erosion on low angle slopes redistributes soil particles but does not create a preferential downslope direction of soil movement (Fernández-Raga et al., 2017). The SOC content close to pit W3 was higher than at pits W2 and W5, although this is a detachment area. This finding could be explained by the fresh surface material collected in a possible recent rainfall event that did not connect the sediment and water from this part of the slope to the lowest position. This could be an example of the rainfall pulses that are characteristic of soil erosion events (short time), which transport some material a few meters but do not connect with the lower 
part of the slope (Brierley et al., 2006; Cavalli et al., 2013; Fryirs et al., 2007; Molina-Sanchis et al., 2016).

In the long term, the observation of SOC in each pit provided more information on the erosion process. At each sampling point, total SOC content decreased with depth: the SOC rate of change in relation to soil depth was highest in W2 $\left(0.011 \mathrm{~g} \mathrm{~kg}^{-1} \mathrm{~cm}^{-1}\right)$ and lowest in pit W5 $\left(-0.0013 \mathrm{~g} \mathrm{~kg}^{-1} \mathrm{~cm}^{-1}\right)$. The variation of SOC with soil depth clearly indicates the areas of erosion where SOC is not stratified but transported downslope by water runoff (Fig. 3).

The annual SOC loss off farm, estimated according to Eq. 2, was $0.20 \mathrm{MgC} \mathrm{ha}{ }^{-1} \mathrm{y}^{-1}$. Considering the annual sediment erosion, the concentration of eroded SOC was $1.3 \%$. The enrichment ratio, calculated as the ratio between the estimated OC content of sediment and the average SOC content in the slope was 2.8. The estimated value of SOC in off farm sediment is similar to the findings of other research carried out in Mediterranean agricultural soils (Sastre et al., 2016). RuizColmenero et al. (2013), in a vineyard under Mediterranean semiarid climate, found that SOC of sediment was $1.3 \%$ with an enrichment value of 2.2. The high values of SOC enrichment in sediment, usually recorded in cultivated land under intensive soil management (Jin et al., 2008), confirmed that the loss of SOC was mainly associated with the fine fractions. The redistribution of SOC due to erosion transport led to a loss of soil fertility inside the vineyard. Considering the value of SOC in the top of the slope (SOC $=0.46 \%$ ), the SOC in the surface layer was reduced along the slope and a total soil fertility loss of $40 \%$.

Considering that soil erosion determines the transport of nutrients associated with particles or aggregates and dissolved in runoff, different authors have highlighted the need to quantify the balance between weathering and erosion considering the burial of $C$ and the significance of the erosion-induced terrestrial carbon sink (Berhe et al., 2007; Stallard, 1998). However, considering the many unknowns concerning the role soil erosion plays in agricultural land (Kirkels et al., 2014), the present study can shed some light on the fate of soil $\mathrm{C}$ as a consequence of soil erosion processes in Mediterranean vineyards.

\subsection{Aromaticity component in WEOC}

Surface wash and runoff affected the distribution of SOC as well as WEOC constituents. SUVA 254 values were used to evaluate WEOC composition (Ma et al., 2016; Weishaar et al., 2003). High SUVA 254 values can be interpreted as relatively hydrophobic material rich in aromatic constituents, while low values represent components with a predominance of hydrophilic, aliphatic molecules (Selberg et al., 2011). SUVA $_{254}$ values for surface soil layers $(0-10 \mathrm{~cm})$ ranged from 2.00 to $0.88 \mathrm{~L} \mathrm{mg}^{-1} \mathrm{~m}^{-1}$ from pits W6 and W2, respectively, decreasing linearly along the slope (Fig. 3). This suggests that WEOC at the detachment site was richer in aromatic constituents with respect to deposition sites. Variations in $\mathrm{SUVA}_{254}$ values along the soil profile did not follow the same pattern as SOC in relation to pole height $\left(\mathrm{SUVA}_{254}=0.049\right.$; Pole height $+1.16 ; p \leq 0.92$ ). For instance, the area next to soil pit W5, which is a deposition site, has a higher value compared to areas close to pits W3 and W2 which are detachment areas. The lower aromaticity of WEOC in deposition areas at the bottom of the slope is correlated to the preferential transportation of hydrophilic soil organic matter compounds with runoff (Ma et al., 2016) and the disruption of soil aggregates and consequent exposure to microbial decomposition during sediment transport (Novara et al., 2016). The SUVA $_{254}$ values decreased in each soil pit with depth (Fig. 3). The top layer contains the highest SOC content and is the layer that is most active for microbial biomass function (Senga et al., 2015). Selective retention of aromatic constituents during leaching could be the reason for the stratification of more labile carbon in deeper soil layers.

The effect of surface runoff on WEOC composition was confirmed by values of SUVA 285 which permits estimation of the proportion of fulvic compounds in WEOC (Hansson et al., 2010) (Fig. 3). The SUVA 285 values decreased from the top to the bottom of the slope, showing that WEOC contains more stable components in erosion than deposition sites.

\subsection{Effect of soil carbon loss on vines vigor}

Soil degradation due to erosion decreases the availability of resources, such as water and nutrients, and consequently has a negative effect on plant vigor, yield and grape quality (Wheeler et al., 2005). In our trial, the slope position significantly affected the pruning mass, ranging from $0.55 \pm 0.22 \mathrm{~kg}$ plant ${ }^{-1}$ close to pit W1 to $0.22 \pm 0.13$ close to pit W6 (Fig. 3d), with the lowest value close to W4. Pruning mass was reduced by $55 \%$ from the top to the bottom of the slope, which corresponds to a SOC decrease of $21 \%$. Pruning mass was strongly correlated with $\mathrm{SUVA}_{285}$ values. Furthermore, the reduction of vigor due to erosion was confirmed by NDVI results (Fig. 3c) as reported by other authors (Durigon et al., 2014). In addition, a general non-linear increasing trend of NDVI can be observed from pit W6 $(\mathrm{NDVI}=0.02)$ to pit W1 $(\mathrm{NDVI}=0.08)$ (Fig. 3d). This increasing NDVI's trend shows a variation of peaks and sinks values in deposition and erosion areas, respectively. Grape yield reduction and loss of grape quality, associated with lower vine vigor, led farmers to increase external inputs. It is well known among farmers that plant vigor is correlated to soil fertility. In order to maintain higher production sustainability, the use of external inputs, such as chemical fertilizer, should be reduced and the organic matter content of soils increased.

\section{Conclusions}

The intensive viticulture has a negative impact on environmental health, increasing the loss of sediment and nutrients and reducing the plant vigor. Hence, to avoid the negative effects of soil fertility reduction on plant vigor, farmers increase the use of external input which lead to a decrease of yield sustainability. The soil erosion rate $\left(16 \mathrm{Mg} \mathrm{ha}^{-1} \mathrm{y}^{-1}\right)$ measured in this study was similar to the values recorded in other Mediterranean vineyards, but we found that the spatial distribution of SOC was mainly determined by soil erosion. This high and non-sustainable soil erosion rate was determined to be $0.20 \mathrm{Mg} \mathrm{ha}^{-1} \mathrm{y}^{-1}$ of SOC offfarm loss with a non-uniform distribution that was dependent on slope topography. Consequently, soil fertility along the slope was reduced by $40 \%$. A strong correlation between SOC and vine vigor parameters (NDVI and pruning weight) was not found. However, NDVI and pruning weight were highly correlated with WEOC components $\left(\mathrm{SUVA}_{254}\right.$ and $\left.\mathrm{SUVA}_{285}\right)$. We found that soil erosion contributed negatively to SOC balance with a noteworthy effect on the dynamics of SOC. The different vine vigor, more than SOC distribution, was determined by SOC potential mineralization due to erosion processes (detachment, transport and deposition) and runoff, as highlighted by the differences in WEOC components. Results of this work highlighted that NDVI, being correlated to erosion, vine vigor and soil fertility, could be a helpful tool for an evaluation of economic and environmental risks due to soil erosion processes in vineyards at the regional scale.

\section{Acknowledgements}

The authors thank Paolo Campo (Funzionario Direttivo, Assessorato Regionale Agricoltura, dello Sviluppo Rurale e della Pesca MediterraneaUfficio Intercomunale di Menfi) for his support with the field work. Eric C Brevik kindly reviewed the manuscript and updated the English.

\section{References}

Aparicio, N., Villegas, D., Casadesu, S.J., Araus, J.L., Royo, C., 2000. Spectral vegetation indices as nondestructive tools for determining durum wheat yield. Agron. J. 92, 83-91. Battany, M.C., Grismer, M.E., 2000. Rainfall runoff and erosion in Napa Valley vineyards: effects of slope, cover and surface roughness. Hydrol. Process. 14 (7), 1289-1304.

Berhe, A.A., Harte, J., Harden, J.W., Torn, M.S., 2007. The significance of the erosioninduced terrestrial carbon sink. AIBS Bull. 57 (4), 337-346. 
Blavet, D., De Noni, G., Le Bissonnais, Y., Leonard, M., Maillo, L., Laurent, J.Y., Roose, E. 2009. Effect of land use and management on the early stages of soil water erosion in French Mediterranean vineyards. Soil Tillage Res. 106 (1), 124-136.

Blum, W.E.H., 2013. Soil and land resources for agricultural production: general trends and future scenarios-a worldwide perspective. Int. Soil Water Conser. Res. 1 (3), $1-14$.

Brevik, E.C., Cerdà, A., Mataix-Solera, J., Pereg, L., Quinton, J.N., Six, J., Van Oost, K., 2015. The interdisciplinary nature of SOIL. Soil 1:117-129. https://doi.org/10.5194/soil-1$117-2015$.

Brevik, E.C., Steffan, J.J., Burgess, L.C., Cerdà, A., 2017. Links between soil security and the influence of soil on human health. Global Soil Security. Springer International Publishing, pp. 261-274.

Brierley, G., Fryirs, K., Jain, V., 2006. Landscape connectivity: the geographic basis of geomorphic applications. Area 38 (2), 165-174.

Burrough, P.A., McDonnell, R.A., 1998. Principles of Geographical Information Systems 1998. Oxford University Press, Oxford (333pp.).

Casalí, J., Giménez, R., De Santisteban, L., Álvarez-Mozos, J., Mena, J., de Lersundi, J.D.V., 2009. Determination of long-term erosion rates in vineyards of Navarre (Spain) using botanical benchmarks. Catena 78 (1), 12-19.

Cavalli, M., Trevisani, S., Comiti, F., Marchi, L., 2013. Geomorphometric assessment of spatial sediment connectivity in small alpine catchments. Geomorphology 188, 31-41.

Cerdà, A., Rodrigo-Comino, J., Giménez-Morera, A., Keesstra, S.D., 2017. An economic, perception and biophysical approach to the use of oat straw as mulch in Mediterranean rainfed agriculture land. Ecol. Eng. 108, 162-171.

Christensen, S., Goudriaan, J., 1993. Deriving light interception and biomass from spectral reflectance ratio. Remote Sens. Environ. 43 (1):87-95. https://doi.org/10.1016/00344257(93)90066-7.

den Biggelaar, C., Lal, R., Wiebe, K., Breneman, V., 2003. The global impact of soil erosion on productivity. I. Absolute and relative erosion-induced yield losses. Adv. Agron. 81, $1-48$.

Doetterl, S., Berhe, A.A., Nadeu, E., Wang, Z., Sommer, M., Fiener, P., 2016. Erosion, deposition and soil carbon: a review of process-level controls, experimental tools and models to address C cycling in dynamic landscapes. Earth Sci. Rev. 154, 102-122.

Durigon, V.L., Carvalho, D.F., Antunes, M.A.H., Oliveira, P.T.S., Fernandes, M.M., 2014. NDVI time series for monitoring RUSLE cover management factor in a tropical watershed. Int. J. Remote Sens. 35:441-453. https://doi.org/10.1080/01431161.2013.871081.

Fernández-Raga, M., Palencia, C., Keesstra, S., Jordán, A., Fraile, R., Angulo-Martínez, M. Cerdà, A., 2017. Splash erosion: a review with unanswered questions. Earth Sci. Rev. 171, 463-477.

Fryirs, K.A., Brierley, G.J., Preston, N.J., Kasai, M., 2007. Buffers, barriers and blankets: the (dis) connectivity of catchment-scale sediment cascades. Catena 70 (1), 49-67.

García-Díaz, A., Bienes, R., Sastre, B., Novara, A., Gristina, L., Cerdà, A., 2017. Nitrogen losses in vineyards under different types of soil groundcover. A field runoff simulator approach in central Spain. Agric. Ecosyst. Environ. 236, 256-267.

Hansson, K., Kleja, D.B., Kalbitz, K., Larsson, H., 2010. Amounts of carbon mineralized and leached as DOC during decomposition of Norway spruce needles and fine roots. Soil Biol. Biochem. 42, 178-185.

Jacinthe, P.A., Lal, R., 2001. A mass balance approach to assess carbon dioxide evolution during erosional events. Land Degrad. Dev. 12, 329-339.

Jin, K., Cornelis, W.M., Schiette, W., Lu, J.J., Buysse, T.M., Baert, H.J., Wu, H.J., Yao, Y., Cai, D.X., Jin, J.Y., Neve, S., Hartmann, R., Gabriels, D., 2008. Redistribution and loss of soil organic carbon by overland flow under various soil management practices on the Chinese Loess Plateau. Soil Use Manag. 24, 181-191.

Keesstra, S.D., Bouma, J., Wallinga, J., Tittonell, P., Smith, P., Cerdà, A., Montanarella, L., Quinton, J.N., Pachepsky, Y., van der Putten, W.H., Bardgett, R.D., Moolenaar, S., Mol, G., Jansen, B., Fresco, L.O., 2016. The significance of soils and soil science towards realization of the United Nations Sustainable Development Goals. Soil 2:111-128. https://doi.org/10.5194/soil-2-111-2016.

Kirchhoff, M., Rodrigo-Comino, J., Seeger, M., Ries, J.B., 2017. Soil erosion in sloping vineyards under conventional and organic land use managements (Saar-Mosel valley, Germany). Cuadernos de Investigación Geográfica. 43(1), pp. 119-140.

Kirkels, F.M.S.A., Cammeraat, L.H., Kuhn, N.J., 2014. The fate of soil organic carbon upon erosion, transport and deposition in agricultural landscapes-a review of different concepts. Geomorphology 226, 94-105.

Lal, R., Pimentel, D. 2008. Soil erosion: a carbon sink or source? Science 319, 1040-1042.

Li, Z., Nie, X., Chang, X., Liu, L., Sun, L., 2016. Characteristics of soil and organic carbon loss induced by water erosion on the loess plateau in China. PLoS One 11 (4), e0154591.

Lieskovský, J., Kenderessy, P., 2014. Modelling the effect of vegetation cover and different tillage practices on soil erosion in vineyards: a case study in Vráble (Slovakia) using WATEM/SEDEM. Land Degrad. Dev. 25 (3), 288-296.

Ma, W., Li, Z., Ding, K., Huang, B., Nie, X., Lu, Y., Xiao, H., Zeng, G., 2016. Stability of soil organic carbon and potential carbon sequestration at eroding and deposition sites. J. Soils Sediments 16:1705-1717. https://doi.org/10.1007/s11368-016-1373-X.

Moges, A., Holden, N.M., 2008. Soil fertility in relation to slope position and agricultural land use: a case study of Umbulo Catchment in Southern Ethiopia. Environ. Manag. 42 (5), 753-763.

Mol, G., Keesstra, S.D., 2012. Soil science in a changing world. Current opinions in environmental. Sustainability 4, 473-477.

Molina-Sanchis, I., Lazaro, R., Arnau-Rosalen, A., Calvo-Cases, A., 2016. Rainfall timing and runoff: the influence of the criterion for rain event separation. J. Hydrosci. Hydraul. 64 (3). https://doi.org/10.1515/johh-2016-0024.
Novara, A., Gristina, L., Saladino, S.S., Santoro, A., Cerdà, A., 2011. Soil erosion assessment on tillage and alternative soil managements in a Sicilian vineyard. Soil Tillage Res. $117,140-147$

Novara, A., Keesstra, S., Cerdà, A., Pereira, P., Gristina, L., 2016. Understanding the role of soil erosion on $\mathrm{CO}_{2}-\mathrm{C}$ loss using $13 \mathrm{C}$ isotopic signatures in abandoned Mediterranean agricultural land. Sci. Total Environ. https://doi.org/10.1016/j.scitotenv.2016.01.095.

Paroissien, J.B., Lagacherie, P., Le Bissonnais, Y., 2010. A regional-scale study of multidecennial erosion of vineyard fields using vine-stock unearthing-burying measurements. Catena 82 (3), 159-168.

Prosdocimi, M., Cerdà, A., Tarolli, P., 2016. Soil water erosion on Mediterranean vineyards: a review. Catena 141, 1-21.

Ramos, M.C., Martínez-Casasnovas, J.A., 2007. Soil loss and soil water content affected by land levelling in Penedès vineyards, NE Spain. Catena 71 (2), 210-217.

Rodrigo-Comino, J.R., Quiquerez, A., Follain, S., Raclot, D., Le Bissonnais, Y., Casalí, J., Pereira, P., 2016a. Soil erosion in sloping vineyards assessed by using botanical indicators and sediment collectors in the Ruwer-Mosel valley. Agric. Ecosyst. Environ. $233,158-170$

Rodrigo-Comino, J.R., Iserloh, T., Morvan, X., Malam Issa, O., Naisse, C., Keesstra, S.D., .. Ramos, M.C., 2016b. Soil erosion processes in European vineyards: a qualitative comparison of rainfall simulation measurements in Germany, Spain and France. Hydrology 3 (1), 6.

Rodrigo-Comino, J.R., Sinoga, J.R., González, J.S., Guerra-Merchán, A., Seeger, M., Ries, J.B., 2016c. High variability of soil erosion and hydrological processes in Mediterranean hillslope vineyards (Montes de Málaga, Spain). Catena 145, 274-284.

Rodrigo-Comino, J.R., Senciales, J.M., Ramos, M.C., Martínez-Casasnovas, J.A., Lasanta, T. Brevik, E.C., Sinoga, J.R., 2017. Understanding soil erosion processes in Mediterranean sloping vineyards (Montes de Málaga, Spain). Geoderma 296, 47-59.

Rouse, J.W., Haas, R.H., Schell, J.A., Deering, D.W., 1973. Monitoring the vernal advancement and retrogradation (green wave effect) of natural vegetation. Prog. Rep. RSC 1978-1. Remote Sensing Center, Texas A\&M Univ., College Station (93p. NTIS No. E73-106393).

Ruiz-Colmenero, M., Bienes, R., Marques, M.J., 2011. Soil and water conservation dilemmas associated with the use of green cover in steep vineyards. Soil Tillage Res. $117,211-223$

Ruiz-Colmenero, M., Bienes, R., Eldridge, D.J., Marques, M.J., 2013. Vegetation cover reduces erosion and enhances soil organic carbon in a vineyard in the central Spain. Catena 104, 153-160.

SAS Institute, 2001. SAS/STAT, Release 8.01. SAS Institute, Cary, NC.

Sastre, B., Barbero-Sierra, C., Bienes, R., Marques, M.J., García-Díaz, A., 2016. Soil loss in an olive grove in Central Spain under cover crops and tillage treatments, and farmer perceptions. J. Soils Sediments:1-16 https://doi.org/10.1007/s11368-016-1589-9.

Selberg, A., Viik, M., Ehapalu, K., Tenno, T., 2011. Content and composition of natural organic matter in water of Lake Pitkjärv and mire feeding Kuke River (Estonia). J. Hydrol. 400, 274-280.

Senga, Y., Hiroki, M., Terui, S., Nohara, S., 2015. Variation in microbial function through soil depth profiles in the Kushiro Wetland, northeastern Hokkaido, Japan. Ecol. Res. 30, 563-572.

Stallard, R.F., 1998. Terrestrial sedimentation and the carbon cycle: coupling weathering and erosion to carbon burial. Glob. Biogeochem. Cycles 12 (2), 231-257.

Steffan, J.J., Brevik, E.C., Burgess, L.C., Cerdà, A., 2017. The effect of soil on human health: an overview. European Journal of Soil Science]->Eur. J. Soil Sci. https://doi.org/ 10.1111/ejss.12451.

Van Oost, K., Six, J., Govers, G., Quine, T.A., Gryze, S., 2008. Response to "soil erosion: a carbon sink or source?". Science 319, 1042

Vermote, E.F., Tanré, D., Deuzé, J.L., Herman, M., Morcrette, J.J., 1997. Second simulation of the satellite signal in the solar spectrum, 6S: an overview. IEEE Trans. Geosci. Remote Sens. 35 (3), 675-686.

Weishaar, J.L., Aiken, G.R., Bergamaschi, B.A., Fram, M.S., Fujii, R., Mopper, K., 2003. Evaluation of specific ultraviolet absorbance as an indicator of the chemical composition and reactivity of dissolved organic carbon. Environ. Sci. Technol. 37, 4702-4708.

Wezel, A., Steinmüller, N., Friederichsen, J.R., 2002. Slope position effects on soil fertility and crop productivity and implications for soil conservation in upland northwest Vietnam. Agric. Ecosyst. Environ. 91 (1), 113-126.

Wheeler, S.J., Black, A.S., Pickering, G.J., 2005. Vineyard floor management improves wine quality in highly vigorous Vitis vinifera 'Cabernet Sauvignon' in New Zealand. N.Z J. Crop. Hortic. Sci. 33, 317-328.

Whitehead, P.G., Futter, M.N., Wilby, R.L., 2006. Impacts of climate change on hydrology, nitrogen and carbon in upland and lowland streams: assessment of adaptation strategies to meet Water Framework Directive Objectives. BHS 9th National Hydrology Symposium, Durham. 2006, pp. 129-134.

Williams, J.R., Jones, C.A., Dyke, P., 1984. A modeling approach to determining the relationship between erosion and soil productivity. Trans. ASAE 27 (1), 129-0144.

WRB, 2006. IUSS Working Group World reference base for soil resources 2006. World Soil Resources Reports No. 103. FAO, Rome. ISBN: 92-5-105511-4.

Zhang, J.H., Wang, Y., Jia, L.Z., Zhang, Z.H., 2017. An interaction between vertical and lateral movements of soil constituents by tillage in a steep-slope landscape. Catena 152, 292-298.

Zingore, S., Murwira, H.K., Delve, R.J., Giller, K.E., 2007. Influence of nutrient management strategies on variability of soil fertility, crop yields and nutrient balances on smallholder farms in Zimbabwe. Agric. Ecosyst. Environ. 119 (1), 112-126. 